\title{
POTENTIAL USE OF LACTOPEROXIDASE ACTIVATION AS A METHOD FOR PRESERVATION OF SHAMI GOAT'S MILK IN NORTH SINAI
}

\section{Y. M. Kamel and H. M. El-Shaer}

Animal and Poultry Production Division, Desert Research Center, El- Mataria, Cairo, Egypt

\section{SUMMARY}

Keeping goat's milk quality is apparently urgent where Bedouins of North Sinai under intensive system were traveled with their animals searching for feed and water and subsequently it would be favorable to have some methods other than refrigeration to prevent bacterial spoilage of raw milk. Lactoperoxidase system is considered an alternative method for preservation where it is a natural antibacterial in milk. Fifty Milk samples were collected from Damscus (Shami) goats of North Sinai governorate. The lactoperoxidase system (LPS) was determined by using ABTS reagent and it was 0.1 unit/ml milk and activated by IDF method. The milk samples were incubated at different temperatures 4, 20, 30 and $40^{\circ} \mathrm{C}$ up to 72 hours. Titratable acidity and $\mathrm{pH}$ as well as bacteriological content were determined. There was no advantage to activate LPS at $4{ }^{\circ} \mathrm{C}$, on the other hand The LPS activation at 20, 30 and $40^{\circ} \mathrm{C}$ improved the keeping quality of the milk to preserve at room temperature in the hot weather up to 72 hours. Therefore, activation of lactoperoxidase system is considered a good method for preservation of milk.

\section{Keywords: Shami goats, lactoperoxidase system, milk microflora}

\section{INTRODUCTION}

Goats are considered one of the farm animals. They are widely accepted as a desert mammal. In Egypt, goats are raised mainly in desert areas as the North Western Coastal zone and the Sinai peninsula. In such areas, they are considered as the cow of the nomads. Their survivability and tolerance to adverse environmental conditions are evidence to their rapid propagation and persistency in equatorial arid zones wherever other species (except camels) cannot survive. In North Sinai, goats constitute the majority of animal population, with an average of $61 \%$ of the total number of animals (Kandil and Ahmed, 1998). The early study of MERC (Middle East Regional Cooperation) project in such area have indicated that there were three systems of production, according to water resources, type of feeding and grazing; namely extensive, semi-intensive and intensive production systems.

Goats were contributed to 67,71 and $80 \%$ of the total goats number in the above three systems, respectively. However, under extensive system, goat's milk seemed to be the main source of animal protein as well as milk products. Therefore, keeping milk quality is apparently urgent where Bedouins under such system were traveled with their animals searching for feed and water and subsequently it would be 
favorable to have some methods other than refrigeration to prevent bacterial spoilage of raw milk, since refrigeration is not adequate.

Such a preservative should therefore satisfy some requirements; it must not react with any of the important constituents of milk, capable of being eliminated before the milk is utilized for human consumption or for industrial processing and has no residual toxic effect after its elimination. (Metwally and Nasr 1992). Lactoperoxidase system as a natural antibacterial in milk offer some advantages compared with the use of hydrogen peroxide (Bjorck, 1987 and Nasr and Metwally, 1990).

Lactoperoxidase system is one of the antimicrobial agents, which is present naturally in goat's milk as well as other mammalian milk. The LPS consists of lactoperoxidase enzyme, thiocynate and hyderogen peroxide. Lactoperoxidase enzyme was found to be affected by breed, age, lactation period, nutrition and health condition while thiocynate was presented in varying amounts depending on dietary intake. Hydrogen peroxidase is generally absent from milk and must be added to activate LPS. However, there is scanty information available concerning the lactoperoxidase system and microflora content of goat's milk. Therefore, this work was carried out to investigate the effect of LPS activation of goat's milk and its quality during storage at different temperatures as well as microflora content.

\section{MATERIALS AND METHODS}

\section{Milk samples:}

Goat milk samples were collected from different locations representing the extensive system in North Sinai governorate (El-Arish, El-Shekh Zoid, Rafah, AlQosima and Nekhle). Milk samples were taken under complete aseptic conditions during the middle of the lactation period and were subjected individually to analysis by California mastitis test to avoid the mastitic samples.

\section{Determination of lps activity:}

Lactoperoxidase system activation in goat milk was achieved according to IDF recommended method (IDF, 1988). Each milk sample was divided into control and test parts. To the test part, $14 \mathrm{mg}$ of sodium thiocyanate per litre of milk was added, mixed and plunged for about 1 minute. Then $30 \mathrm{mg}$ of sodium percarbonate was added and the sample was stirred for another 2-3 minutes. Each part was divided into 4 portions; each portion was incubated at 4, 20, 30 and $40^{\circ} \mathrm{C}$. Samples for Bacteriological analysis and determination of acidity and $\mathrm{pH}$ were investigated after activation ( 0 time) and after $6,12,18,24,36,48$ and 72 hours.

\section{Microbiological analysis}

\section{A. Preparation of bacteriological media:}

Standard plate count agar (SPCA): Commercially dehydrated medium (BritianaArgentin) was used for preparation of plate count agar plates for counting the total aerobic bacterial count. Soluble starch was added at the concentration of $0.1 \%$ to count spore-forming bacteria.

Violet Red Bile Glucose Agar (VRBA): Commercially dehydrated medium (DIFCO-USA) was used for enumeration of coliforms according to ISO: 1986. 
MRS agar: Commercially dehydrated medium (Britiana-Argentin) was used for counting the Lactic acid bacteria.

\section{B. Enumeration of micro-organisms:}

Total Aerobic bacterial count: The method of plating, incubation and counting was followed as suggested by IDF: 1987 . The plates were incubated at $37^{\circ} \mathrm{C}$ for 72 hours.

Enumeration of Coliforms: VRBA was used for counting of Coliforms as recommended by ISO:1986. Incubation was done at $37^{\circ} \mathrm{C}$ for 48 hours. Colonies having more than $1.5 \mathrm{~mm}$ in size were considered for coliform count. This was confirmed by randomly picking up at least 5 colonies from the plates and subjected them to Gram's staining and catalase test according to Sperk, 1984.

Lactic acid bacterial count: MRS plates were incubated at $37^{\circ} \mathrm{C}$ for 48 hours. Colonies that appeared large and white regarded as Lactobacilli.

Aerobic spore forming bacterial count: Five $\mathrm{ml}$ of milk samples was aseptically transferred to sterile test tubes that were transferred to thermostatically controlled water bath to give $80^{\circ} \mathrm{C}$ heating for 12 minutes. After the required heating time, test tubes were immediately assigned to a beaker containing chilled water. Appropriate dilutions of the samples were pour plated using standard plate count agar containing $0.1 \%$ soluble starch. Incubation was done at $32^{\circ} \mathrm{C}$ for 48 hours.

\section{Measuring acidity and $\mathrm{pH}$ :}

Acidity and $\mathrm{pH}$ were determined according to Ling (1963).

\section{RESULTS AND DISCUSSION}

Although the share of goat's milk in milk production is limited, it nevertheless plays a vital role in certain areas as rural and new reclaimed areas like North Sinai governorate. Reasons for such low level of goat's milk production in such areas are mainly due to inadequate nutrition, where unfavorable conditions such as high aridity and/or limited forage availability. Animals rose in such conditions, with proper diet, could double or treble their yield and increase its quality (Jaouen, 1978).

The most practical technique of milk preservative during collection and transportation is cooling. This is, so far, not available in most tropical and developing regions such as North Sinai governorate where the individual small farms and the less developed road systems enlarge the problem of collection. Consequently, it is essential to obtain some methods other than refrigeration i.e. "chemical preservative" to hinder bacterial spoilage of raw milk.

There are a numerous preservatives including antibiotics, which have been employed or suggested for preservation of milk (Bjorck, 1987). None of these, however, fulfills the above-mentioned requirements. The recommended quantities of hyderogen peroxide to be added to milk range from 100-800 ppm. At higher concentration $(>800 \mathrm{ppm})$ a distinct changes could exist in the biochemical activity and chemical composition. These changes include taste, nutritive value and affect processing steps of milk (Luck, 1962 and Tenovuo and Makinen, 1976).

Although some studies has been carried out on goat's milk (Zapico et al., 1991, Saad de Schoos et al., 1999), no detailed information on such variations are available in the literature.

Lactoperoxidase activity in goat milk was determined using 2,2 ${ }^{\circ}$-azino-di-(3ethyl-benzthiazoline-6-sulfonic acid) $\{$ ABTS $\}$ reagent; it was 0.1 units $/ \mathrm{ml}$ in average. 
This estimated value was less than those reported for either ewes ( 0.14 to 2.28 unit $/ \mathrm{ml} \mathrm{milk}$ ), cow $(1.4 \mathrm{unit} / \mathrm{ml})$ or camel $(2.9 \mathrm{unit} / \mathrm{ml})$ as reported by Medina et al., 1989; Stephens et al., 1979 and El-Nawawy, 1993 respectively.

The effect of activation of lactoperoxidase system in goat milk on the changes in the titratable acidity and $\mathrm{pH}$ at different temperatures of storage up to 72 hours is recorded in Table (1).

The present study revealed that there was neither change in titratable acidity nor $\mathrm{pH}$ in both control and activated milk samples up to 72 hours of incubation at $4^{0} \mathrm{C}$ as shown in figures (1\&5). The control samples stored at $20^{\circ} \mathrm{C}, 30^{\circ} \mathrm{C}$ and $40^{\circ} \mathrm{C}$ revealed an increase in acidity with the increase in time as seen in figures $(2,3,4,6,7 \& 8)$. Milk was coagulated after 72,48 and 36 hours for the samples incubated at $20^{\circ} \mathrm{C}$, $30^{\circ} \mathrm{C}$ and $40{ }^{\circ} \mathrm{C}$ respectively. The same trend was also recorded for the decrease in the $\mathrm{pH}$ values along the time of incubation. This trend is attributed to denaturation of milk protein as a result of lactose converted to lactic acid by the action of the microflora content. This result was in agreement with that of Lowensten et al. 1992.

The $\mathrm{pH}$ is an important indicator for antimicrobial potential of the peroxidase system (Kersten et al., 1981) The $\mathrm{OSCN}^{-}$anion is the major oxidation product of the system at the $\mathrm{pH}$ range 6.5-7.0 (Pruitt et al., 1983). At law $\mathrm{pH}$ the major product is the neutral molecule (HOCSN) and due to its uncharged nature, may penetrate microbial cell membranes more ready than $\mathrm{OSCN}^{-}$. This suggestion is supported by observation showing antibacterial effects of the LPS are greater at law pH (Kersten al., 1981 and Thomas, 1981). Our study revealed that $\mathrm{pH}$ trended to decline after 36 hours of incubation at $20^{\circ} \mathrm{C}, 30^{\circ} \mathrm{C}$ and $40^{\circ} \mathrm{C}$ in the control samples while nearly showed no change in the LPS activated ones.

The effect of LPS activation on the changes of microflora content of goat's milk stored at different temperatures was shown in Table (2).

The oxidation of sulfhydryl $(\mathrm{SH})$ groups of bacterial enzymes and other proteins has been considered to be the key to the antibacterial action of the LPS (Aune and Thomas, 1978, Mickelson, 1966 and 1979 and Thomas \& Aune, 1978). Moreover, the bacterial cytoplasmic membrane is obviously structurally damaged or changed because organisms exposed to LPS immediately, uptake of glucose, purines, pyrimidines and amino acids as well as synthesis of protein, DNA and RNA is also inhibited (Reiter, 1978 and Reiter and Harnulv, 1984).

In addition, results confirmed that the length of the antibacterial effect achieved by activation of the LPS is inversely related to the storage temperature of the milk. Results of (Bjorck et al., 1975, Reiter \& Hamulv, 1982, Reiter et al., 1976 and Zajac et al., 1983) supported our results well. The preservative effect is not only due to the reduction of the Gram negative flora but also to the suppression of acid development by contaminating lactic acid bacteria (Harnulv \& Kandesamy, 1981 \& 1982 and Reiter \& Harulv, 1982).

The count of different types of raw milk microflora as total aerobic bacteria, aerobic spore forming bacteria and lactic acid ones revealed the good quality of the fresh milk (0 time). Although the count of the microflora of milk samples that stored at $4^{0} \mathrm{C}$ was nearly constant along the incubation period, the microbial count of Lactoperoxidase activated samples had an important decrease when compared with those of control as shown in figures ( $9 \& 13)$. 


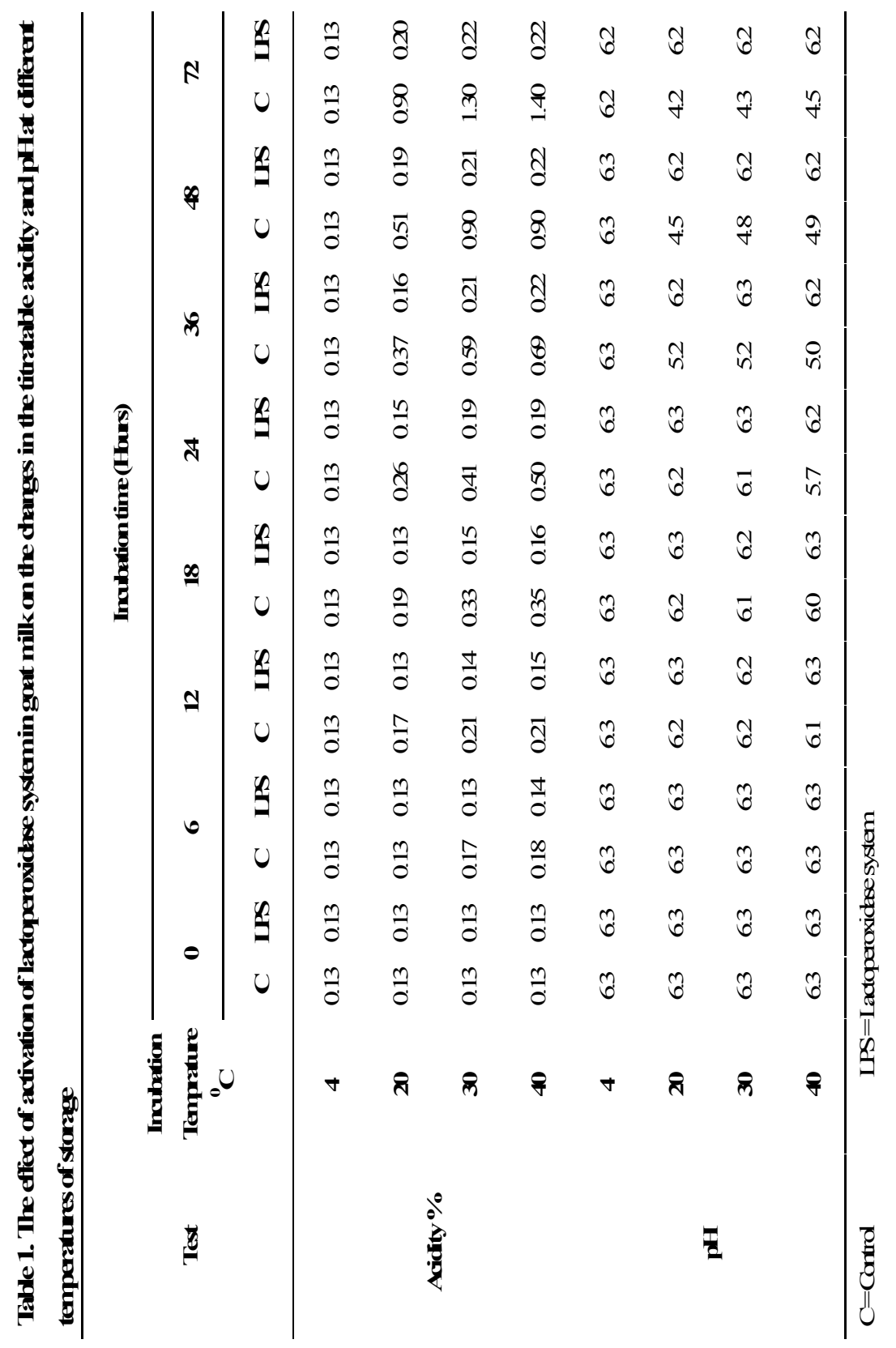




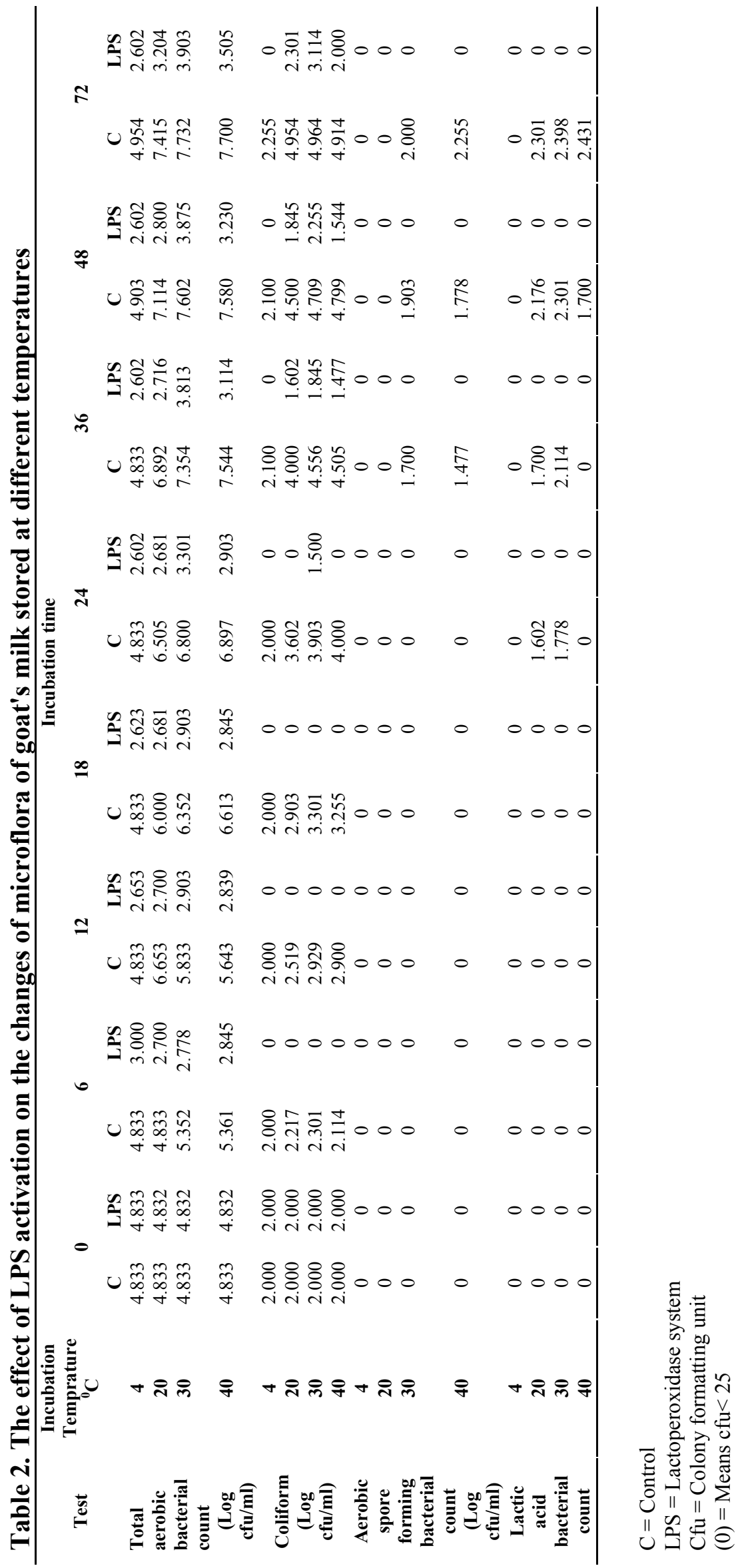



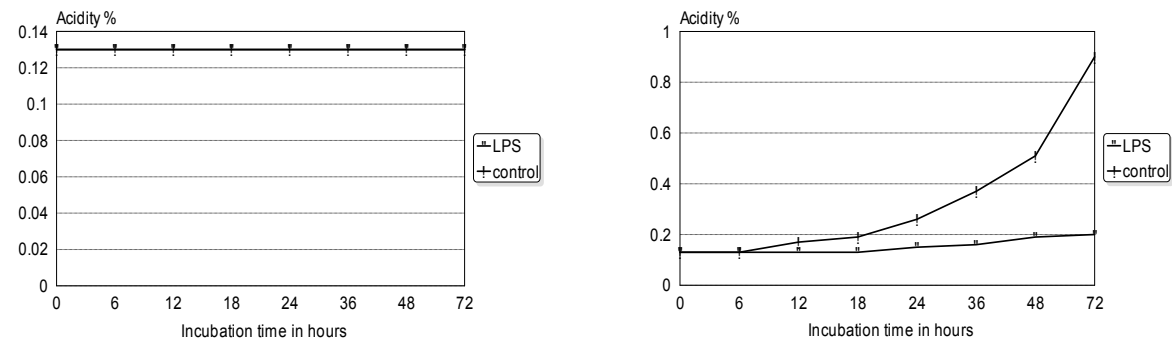

Figure (1): Effect of LPS on the changes of aciditv at $4^{\circ} \mathrm{C}$

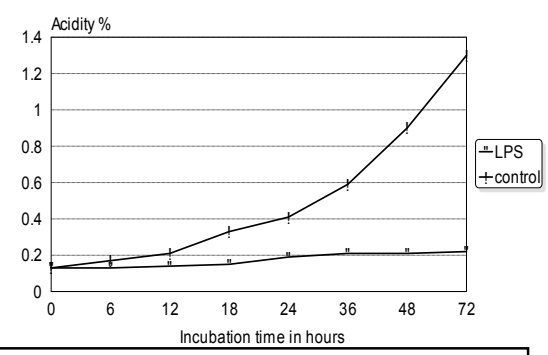

Figure (3): Effect of LPS on the changes

of acidity at $30^{\circ} \mathrm{C}$

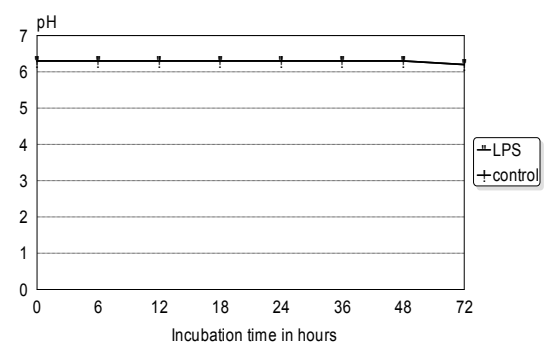

Figure (5): Effect of LPS on the changes of $\mathrm{pH}$ at $4^{\circ} \mathrm{C}$
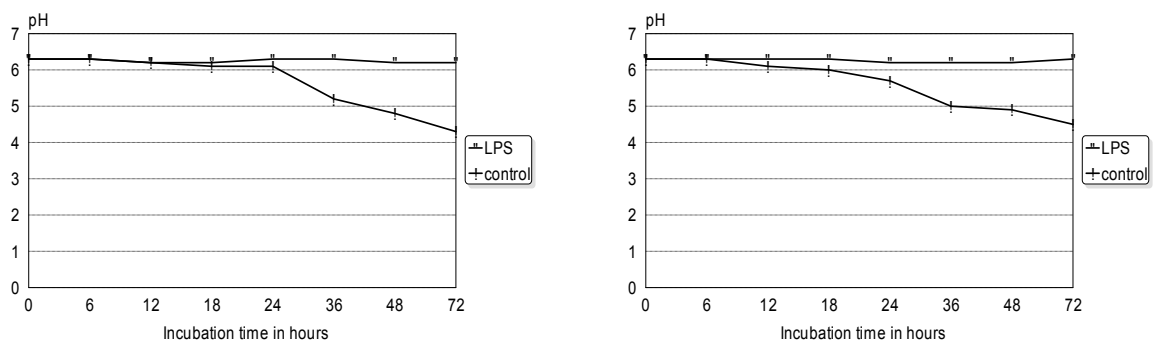

Figure (7): Effect of LPS on the changes of $\mathrm{pH}$ at $30^{\circ} \mathrm{C}$

Figure $(\Im)$ : Effect of LPS on the changes of acidity at $20^{\circ} \mathrm{C}$

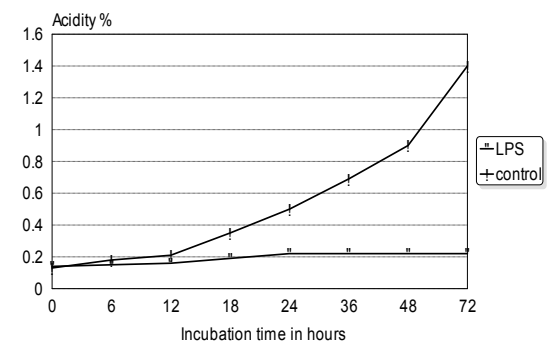

Figure (4): Effect of LPS on the changes of acidity at $40^{\circ} \mathrm{C}$

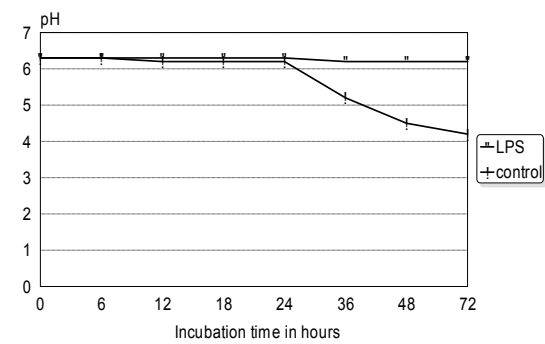

Figure (6): Effect of LPS on the changes of $\mathrm{pH}$ at $20^{\circ} \mathrm{C}$

Figure (8): Effect of LPS on the changes of $\mathrm{pH}$ at $40^{\circ} \mathrm{C}$ 
Total aerobic bacterial count began to increase after 6 hours incubation at $30^{\circ} \mathrm{C}$ and $40^{\circ} \mathrm{C}$, while was slower up to 12 hours at $20^{\circ} \mathrm{C}$. This increasing was continued along the time up to 72 hours in the control samples. An inverse trend was observed for LPS activated samples as shown in figures (10-12).

Concerning Coliforms, their number showed increasing numbers as time goes on in the control samples, while LPS activated samples showed no growth up to 24 hours of incubation at $20^{\circ} \mathrm{C}, 30^{\circ} \mathrm{C}$ and $40^{\circ} \mathrm{C}$. The growth began to appear after 24 hours and persist in increasing after 48 hours and then increased rapidly after 72 hours of incubation as shown in figures (14-16).

Regarding aerobic spore forming bacterial count, no growth was observed in the LPS activated samples. The growth was shown after 36 hours of incubation at $30^{\circ} \mathrm{C}$ and $40^{\circ} \mathrm{C}$ and increased along the time as shown in figures (17\& 18$)$.

Lactic acid bacterial count had the same trend of that of the aerobic spore forming with difference in their growth appeared after 18 and 24 hours of incubation at $30^{\circ} \mathrm{C}$ and $20^{\circ} \mathrm{C}$ respectively as shown in figures (20-21).

In conclusion, the application of LPS as a temporary milk preservative having several advantages i.e. simple, have specific antimicrobial effect and there is no any toxicological risks (El Nawawy, 1993). Therefore, it can be applied to prolong milk preservation. Although the law content of lactoperoxidase enzyme in the milk of goat, it gives strong response to activation. So, the IDF method for LPS activation can be used to preserve goat milk as a temporary method where adequate milk cooling is not available without any toxic risks.

However, the result revealed that the change in the acidity, $\mathrm{pH}$ and the microbial content were slightly limited up to 24 hours while the major changes were recorded after 48 hours. There was no advantage to activate LPS at $4^{0} \mathrm{C}$, on the other hand; the LPS activation at $20^{\circ} \mathrm{C}, 30^{\circ} \mathrm{C}$ and $40^{\circ} \mathrm{C}$ improved the keeping quality of the milk kept at room temperature in the hot weather up to 72 hours.

The main beneficiaries will be for Bedouins women who generally manage their dairy animals. They will improve milk quality, better marketing and manufacture their surplus milk to the urban centers and to reduce milk losses. This will result in a substantial increase in cash income for the household where the available agriculture activity is not available. 

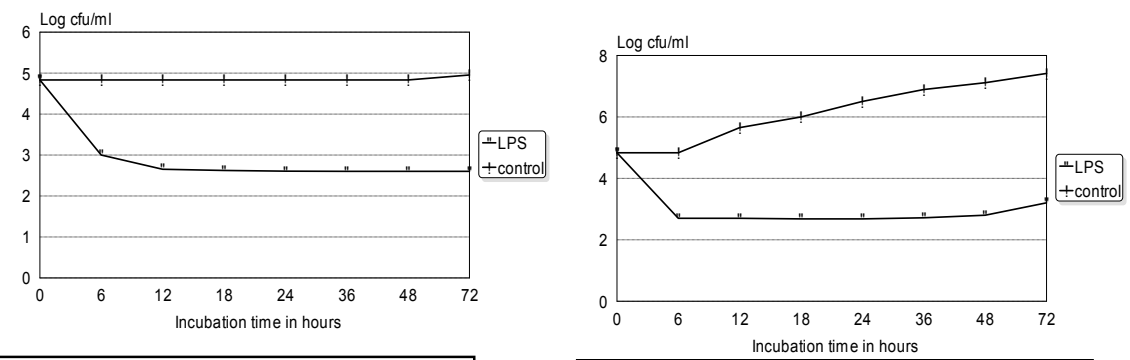

Figure (9): Effect of LPS on the changes of total aerobic bacterial count at $4^{\circ} \mathrm{C}$

Figure (10): Effect of LPS on the changes of total aerobic bacterial count at $20^{\circ} \mathrm{C}$

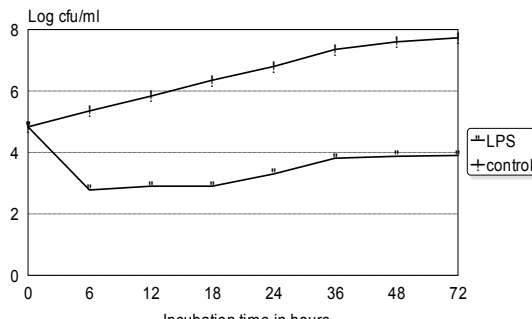

Figure (11): Effect of LPS on the changes of total aerobic bacterial count at $30^{\circ} \mathrm{C}$
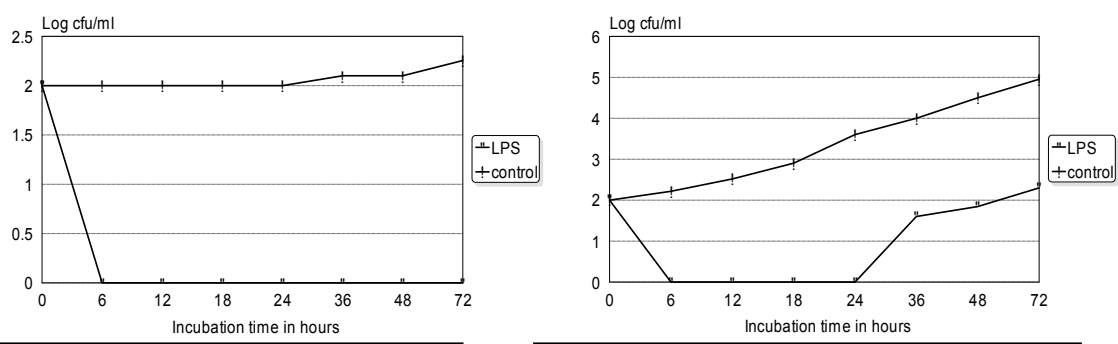

Figure (13): Effect of LPS on the changes of colifoirms count at $4^{\circ} \mathrm{C}$
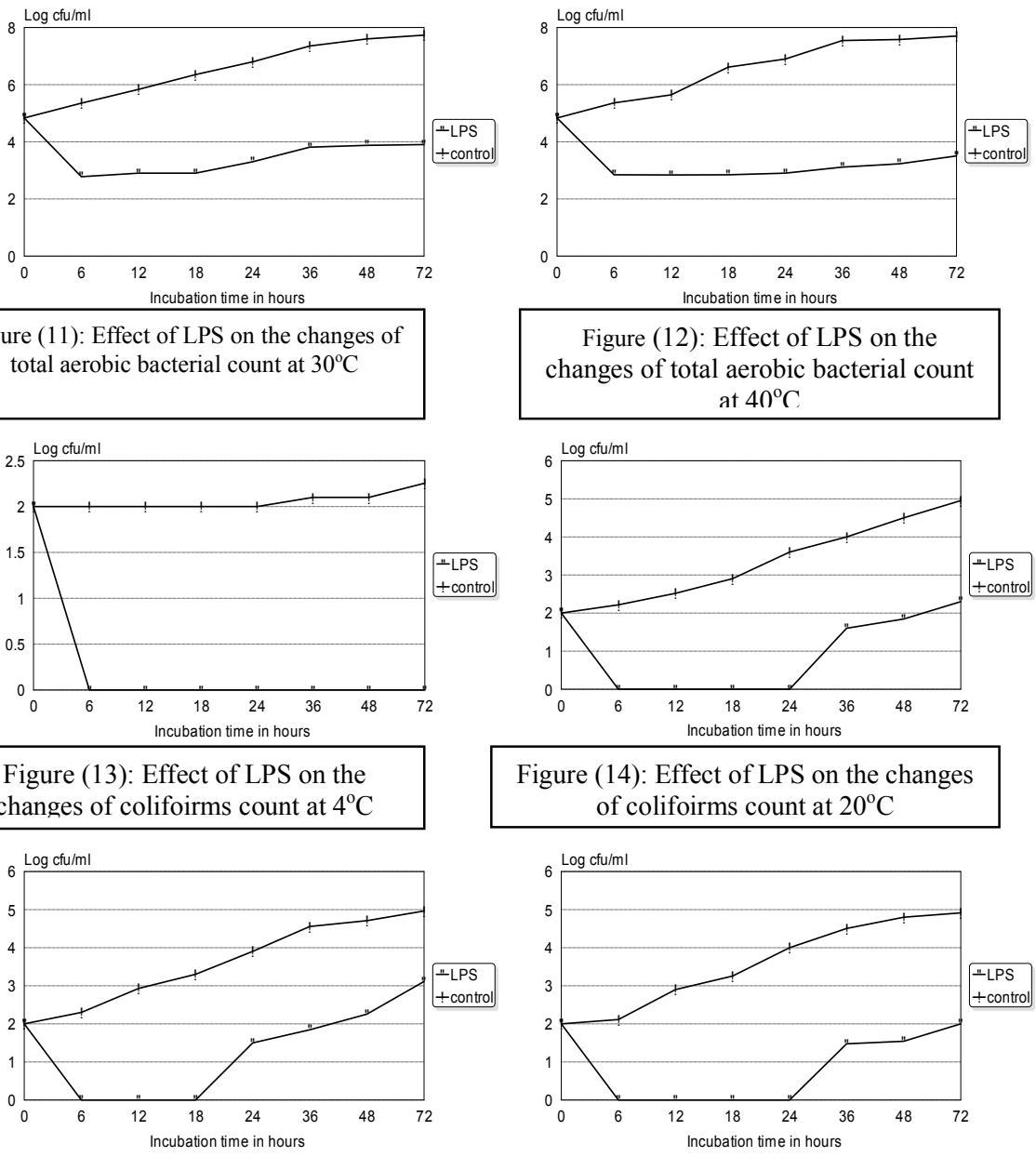

Figure (12): Effect of LPS on the changes of total aerobic bacterial count at $40^{\circ} \mathrm{C}$

Figure (14): Effect of LPS on the changes of colifoirms count at $20^{\circ} \mathrm{C}$

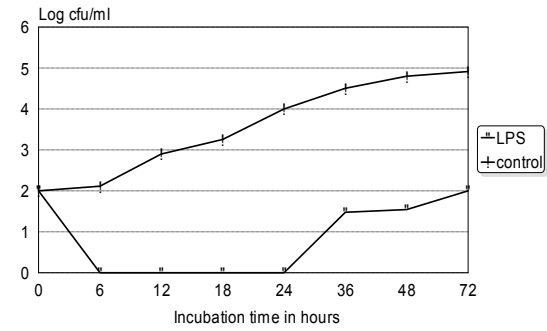

Figure (15): Effect of LPS on the changes of colifoirms count at $30^{\circ} \mathrm{C}$

Figure (16): Effect of LPS on the changes of colifoirms count at $40^{\circ} \mathrm{C}$ 


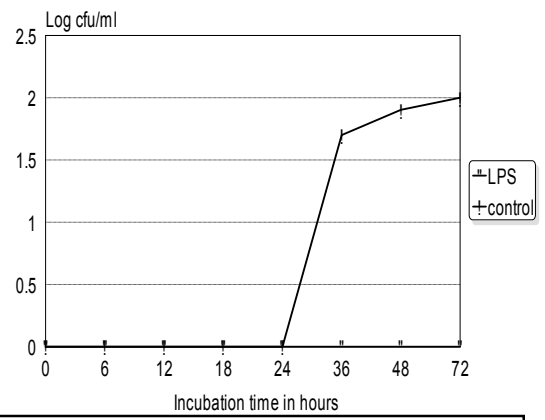

Figure (17): Effect of LPS on the changes of aerobic spore forming bacterial count at $30^{\circ} \mathrm{C}$

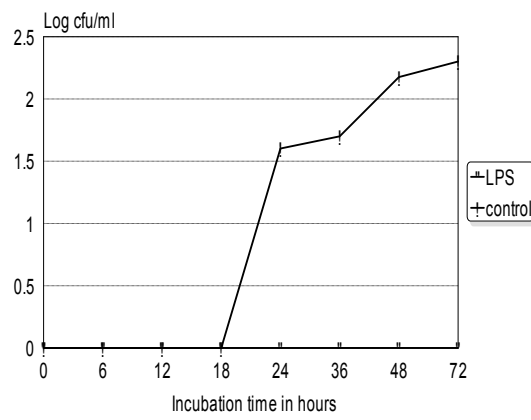

Figure (19): Effect of LPS on the changes of lactic acid bacterial count at $20^{\circ} \mathrm{C}$

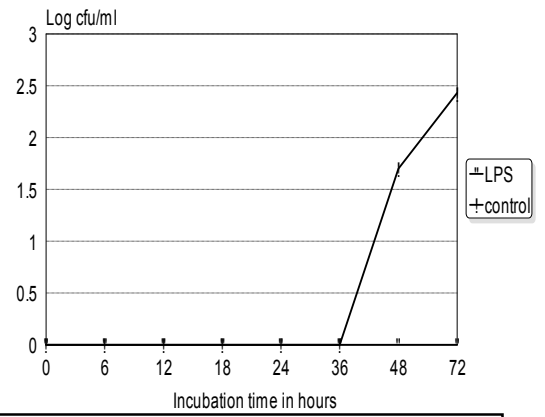

Figure (21): Effect of LPS on the changes of lactic acid bacterial count at $40^{\circ} \mathrm{C}$

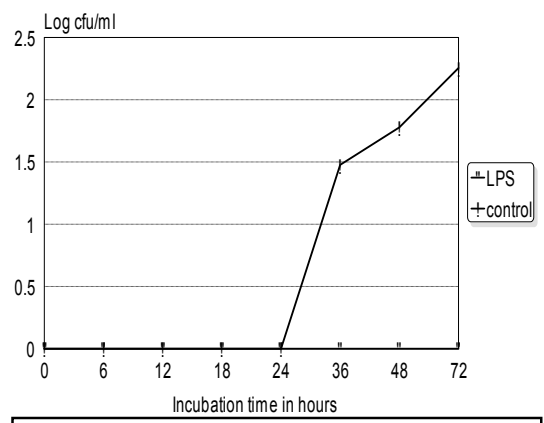

Figure (18): Effect of LPS on the changes of aerobic spore forming bacterial count at $40^{\circ} \mathrm{C}$

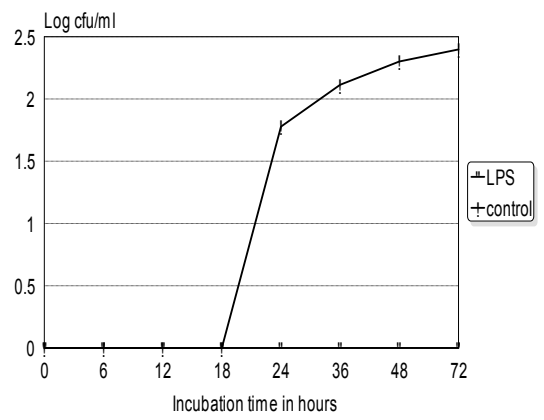

Figure (20): Effect of LPS on the changes of lactic acid bacterial count at $30^{\circ} \mathrm{C}$ 


\section{ACKNOWLEDGMENT}

This research was supported under Grant No., M18-001, Middle East Regional Cooperation (MERC) program, Bureau for Economic Growth, Agriculture and Trade, U. S. Agency for International Development.

\section{REFERENCES}

Aune, T. M. and E. L. Thomas, 1978. Oxidation of protein sulfhydryls by products of peroxidase-catalyzed oxidation of thiocyanate ion. Biochemistry, 17: 1005-1010.

Bjorck, L., C. G. Rosen, V. Marshall and B. Reiter, 1975. Antibacterial activity of the lactoperoxidase system in milk against pseudomonas and other Gram-negative bacteria. Applied Microbiology 30: 199-204.

Bjorck L. 1987. Preservation of milk by chemical means. In: International Dairy Federation, Bulletin 221, Session B, 1040 Brussels (Belgium)

El Nawawy, M.A., 1993. Lactoperoxidase in camel milk and its effect on Listeria monocytogenes Annals of Agric. Sc. Moshtohor, Vol. 31 (3).

Harnulv, B. G. and C. Kandesamy, 1981. Possibilities to use the lactoperoxidase system in Tropical countries to save milk from an early spoilage. IDF symposium on the "Bacteriological Quality of raw milk". Kiel FRG, September 1981, p. 47.

Harnulv, B. G. and C. Kandesamy, 1982. Increasing the keeping quality of milk by activation of its lactoperoxidase system. Results from Sri Lanka, Milchwis senschaft, 37: 454-457.

IDF, 1987. Milk and milk products. Enumeration of microorganisms- colony count at $30^{\circ} \mathrm{C}$. IDF Standard 100A.

IDF, 1988. Code of practice for the preservation of raw milk by the lactoperoxidase system. Rev30: 309.

ISO, 1986. Milk and milk products. Enumeration of coliforms Part-I colony count at $30^{\circ} \mathrm{C}$ Standard 5541: 1 .

Jaouen, J.C.Le, 1978. Etude de la vocation laitiere de la chevne dans le cadne systemes laitiera intensifa et de systemes misles iaitviande XX int. Dairy congreso. BFC. Paris

Kandil, H. M. and A. M. Ahmed, 1998. Sheep performance raised on natural ranges with energy supplements in North Sinai. J. Agric. Sci. Mansoura Univ., 23 (2): $163-169$

Kersten, H. W., W. R. Moorer and R. Wever, 1981. Thiocyanate as a cofactor in myeloperoxidase activity against Streptococcus mutans. J. Dent Res., 60: 83837.

Ling, E.R. 1963: A text book of dairy chemistry. Vol. 2. Pratical. $3^{\text {rd }}$ Ed., Champan and Halls. London. England.

Lowensten, M., H. M. Barnhart, J.F. Frank and S. J Sperk, 1992. Culture products made from goat milk. Goat handbook, E-5.

Luck, H., 1962. The use of hyderogen peroxide in milk and dairy products. In: FAO/WHO milk hygiene, WHO Monograph series No. 48 Geneva.

Medina, M., P. Gaya P. and M. Nunez, 1989. The lactoperoxidase system in ewe's milk: Levels of lactoperoxidase and thiocyanate. Letters in applied microbiology, 8: 147-149.

Metwally, M.M.K and M.M. Nasr, 1992. Preservation of raw milk by activation of Lactoperoxidase system. Egypt. J. Food Sci., Vol. 20 No.2, pp. 175-196. 
Mickelson, M.M., 1966. Effect of lactoperoxidase and thiocyanate on the growth of Streptococcus pyogenes as Streptococcus agalactiae in chemically defined culture medium. J Gen. Microbiol., 43: 31-43.

Mickelson, M.M., 1979. Antibacterial action of lactoperoxidase- thiocyanatehydrogen peroxide on Streptococcus agalactiae. Appl. Environ. Microbiol., 38: 821-856.

Nasr, M.M and M.K. Metwally, 1990. Recommendation for using Lactoperoxidase system in milk preservation. The Arabic conference for Developing and Completing the food industry, 22-25 Sept. Sabha, Libya.

Pruitt, K.M., B.M. Rahemtulla and J. Tenovuo, 1983. Detection of the hypothiocyanate (OSCN-) ion in human parorid saliva and the effect of $\mathrm{pH}$ on OSCN- generation in the salivary peroxidase antimicrobial system. Archs Oral Biol., 28:517-525.

Reiter, B. 1978. Review of the progress of dairy science: Antimicrobial systems in milk. J. Dairy Res., 45: 131-147.

Reiter, B and B. C. Harnulv, 1982. The preservation of refrigerated and uncooled milk by its natural lactoperoxidase system. Dairy Ind. Int., 47: 12-15.

Reiter, B. and G. Harnulv, 1984. Lactoperoxidase antibacterial system: natural occurance, biological functions and practical applications. J. Food protect., 47: 724-732.

Reiter, B., V.M. Marshall, L. Bjorck and C.G. Rosen, 1976. Non-specific bactericidal activity of lactoperoxidase, thiocyanate, hydrogen peroxide system of milk against Eschericia coli and some gram negative pathogens. International Immun., 13: 800-807.

Sperk, M L., 1984. Compendium of the methods for the microbiological examination of food $2^{\text {nd }}$ Ed. APHA Publication, Washinton. P.914.

Saad,de Schoos, S., G. Oliver and F. M. Fernandez, 1999. Relationships between lactoperoxidase system components in Creole goat milk. Small Ruminant Research 32: 69-75.

Stephens, S., R.A. Harkness and S.M. Cockle, 1979. Lactoperoxidase activity in guinea pig milk and saliva. Correlation in milk of lactoperoxidase activity against E.coli. British J. Experm. Pathol. 60: 252.

Tenovuo, J. and K.K. Makinen, 1976. Concentration of thiocyanate and ionizable iodine in saliva of smokers and non smokers. J. Dent. Res., 55: 661-663.

Thomas, E.L., 1981. Lactoperoxidase - catalyzed oxidation of thiocyanate: the equilibria between oxidized forms of thiocyanate. Biochemistry, 20: 2272-2280.

Thomas, E. L and T. M. Anue, 1978. Susceptipility of Eschericia coli to bactericidal action of lactoperoxidase, peroxide and iodide or thiocyanate. Antimicrob. Agents Chemother, 13: 261-265.

Zajac, M., J. Gladys, M. Skarzynska, G. Harnulv and L. Bjorck, 1983. Changes in bacteriological quality of raw milk stabilized by activation of its lactoperoxidase system and stored at different temperatures. J. Food Prot., 46: 1065-1070

Zapico, P., P. Gaya, M. Nunez, M. Medina and M. De-Paz, 1991. Influence of breed, animal and days of lactation on peroxidase system components in gota milk. Journal of Dairy Science 74, 783-787. 
إمكانية إستخام تنشيط إنزيم اللاكتوبيروكسيديز كوسيلة لحفظ لبن الماعز الثامي بشمال سيناء ياسر محمود كامل و حسن محمد الثاعر مركز بحوث الصحراء، المطرية، القاهرة

يعد الحفاظ على جودة لبن الماعز حالة ملحة في ضوء أسلوب التربية المكثفة الذي يتبعه بدو شمال سيناء

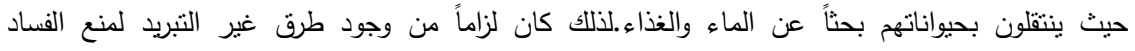

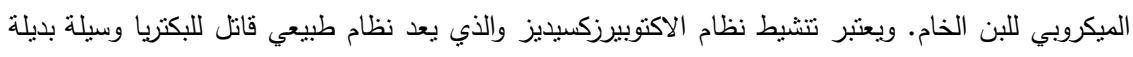

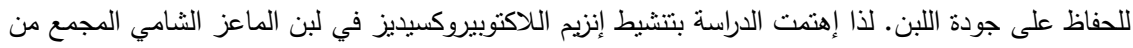

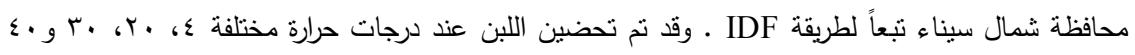

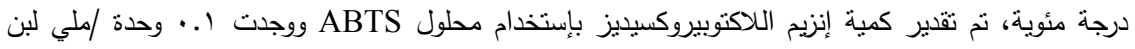

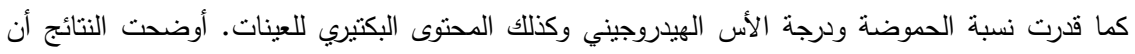

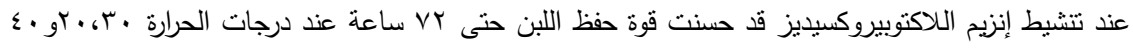
درجة مئوية بينما ظلت الجودة كما هى عند دجة الحرارة ؛ درجة مئوية في العينات المعاملة والحاكمة. 